\title{
A 100-Year Review: Stress physiology including heat stress ${ }^{1}$
}

\author{
R. J. Collier, ${ }^{2}$ B. J. Renquist, and Y. Xiao \\ School of Animal and Comparative Biomedical Sciences, University of Arizona, Tucson 85719
}

\begin{abstract}
Stress is an external event or condition that places a strain on a biological system. The animal response to a stress involves the expenditure of energy to remove or reduce the impact of the stress. This increases maintenance requirements of the animal and results in loss of production. The biological response to stress is divided into acute and chronic phases, with the acute phase lasting hours to a few days and the chronic phase lasting several days to weeks. The acute response is driven by homeostatic regulators of the nervous and endocrine systems and the chronic phase by homeorhetic regulators of the endocrine system. Both responses involve alterations in energy balance and metabolism. Thermal environment affects all animals and therefore represents the largest single stressor in animal production. Other types of stressors include housing conditions, overcrowding, social rank, disease, and toxic compounds. "Acclimation" to a stress is a phenotypic response developed by the animal to an individual stressor within the environment. However, under natural conditions, it is rare for only one environmental variable to change over time. "Acclimatization" is the process by which an animal adapts to several stressors within its natural environment. Acclimation is a homeorhetic process that takes several weeks to occur and occurs via homeorhetic, not homeostatic, mechanisms. It is a phenotypic change that disappears when the stress is removed. When the stress is severe and not relieved by acclimatization or management changes, the animal is considered chronically stressed and is susceptible to increased incidence of disease and poor health. Milk yield and reproduction are extremely sensitive to stress because of the high energy and protein demands of lactation and the complexity of the reproductive process and multiple organs that are involved. Improvements in protection of animals against stress require improved education of producers to recognize stress and methods for estimating degree of stress on animals.
\end{abstract}

Received August 11, 2017.

Accepted August 22, 2017.

${ }^{1}$ This review is part of a special issue of the Journal of Dairy Science commissioned to celebrate 100 years of publishing (1917-2017).

${ }^{2}$ Corresponding author: rcollier@ag.arizona.edu
Key words: acclimation, homeorhesis, strain, stress

\section{INTRODUCTION}

Hans Selye (1936) first introduced the concept of stress as "the non-specific response of the body to any demand," and many attempts have been made to refine its meaning (Friend, 1991; Appendix Table A1). However, the definition remains ambiguous and the word is used differently in different contexts. As pointed out by Schulte (2014), the variability in the definition of stress may stem from the fact that stress research has developed relatively independently across several fields of biology, with substantial gulfs between those interested in stress from a biomedical perspective and those interested in the effects of stressors in natural populations (Bijlsma and Loeschcke, 2005; Boonstra, 2013).

For the purpose of consistency, we will define stress as an "external event or condition." We will further define a stressor as the component of the environment that places a strain on a biological system. Examples of stressors are shown in Table 1 and include thermal environment, management, social interaction, environmental contaminants, and disease, to name a few. Stress is a threat to homeostasis because it always increases the maintenance requirements of domestic animals. Because energy demands alter animal production, we are restricting this review to "external challenges that require a change in maintenance output to meet the challenge." One of the earliest estimates of maintenance energy requirements in cattle was published by Washburn (1938). Brody (1956) reviewed the effects of thermal environment on basal metabolism. The increase in maintenance requirement by stress is of real concern to production animal systems because it increases costs, reduces efficiency, and leads to lower profitability of an animal enterprise. The reason a stress increases maintenance cost is because energy must be expended to return the animal to homeostasis of body function. This energy must come from net energy for production because it is not physically possible to remove it from net energy for maintenance. The environmental temperature below which the body produces extra heat to meet the thermostatic heat requirement is termed the "lower critical temperature" and was first estimated 
Table 1. Partial list of types of stressors and biological responses to them ${ }^{1}$

\begin{tabular}{lll}
\hline Stressor & Symptom & Physiological system activated or inhibited \\
\hline Heat & Elevated body temperature & Heat loss mechanisms increased; decreased phagic drive \\
Cold & Reduced body temperature & $\begin{array}{l}\text { Heat gain mechanisms enhanced; heat loss mechanisms reduced; feed intake } \\
\text { enhanced }\end{array}$ \\
Infection & Elevated body temperature & $\begin{array}{l}\text { Immune system activated; decreased phagic drive; hypothalamic body } \\
\text { temperature setpoint altered }\end{array}$ \\
Poor housing & Increased lameness & $\begin{array}{l}\text { Hypothalamic-pituitary-adrenal axis activated; reduced phagic drive } \\
\text { Poor nutrition }\end{array}$ \\
Deficiency symptom varies with & $\begin{array}{l}\text { Mobilization of nutrient reserves; activation of pituitary-adrenal axis; altered } \\
\text { behavior }\end{array}$ \\
Environmental & Hepatotoxicity & $\begin{array}{l}\text { Liver function reduced; multiple organ damage; hypothalamic-pituitary-adrenal } \\
\text { axis activated }\end{array}$ \\
Social & Altered behavior & Feed intake reduced; hypothalamic-pituitary-adrenal axis activated
\end{tabular}

${ }^{1}$ References: Bauman and Currie, 1980; Collier et al., 1982b; Friend, 1991; Coulombe, 1993; Bauman (2000); Collier and Gebremedhin, 2015; Chebel et al., 2016.

by Kleiber (1961) and confirmed by Hamada (1971). The environmental temperature above which the body starts storing heat and losing milk yield was established by Berman et al. (1963, 1985). For other stressors, we do not yet have specific end points by which to measure the relationship between the stress and loss in productivity of cattle. A key opportunity for the future will be to improve our ability to identify and measure levels of various stressors and their impact on animals in order to develop strategies to reduce the effects of those stressors on dairy animals (Appendix Table A1).

\section{STRESS RESPONSE}

Animals mount a response to a stress that involves behavioral, metabolic, and physiological changes at multiple levels of vertebrate organization from subcellular to the whole animal (Selye, 1936; Collier and Gebremedhin, 2015). The stress response is divided into 2 phases: acute and chronic (Friend, 1991). Acute stress responses last from a few minutes after the beginning of the stress to a few days (Horowitz, 2001). Activation of the acute response to stress is initiated by various receptors that respond to changes in the environment (Collier and Gebremedhin, 2015; Figure 1). The afferent pathways for the stress transmit this information to the central nervous system, including the thalamus and hypothalamus, where setpoints are controlled, and to the cortex for perception (Figure 1). These centers then activate various efferent pathways to effect a response to the environment (Figure 1). The acute response is driven by the autonomic nervous system promoting release of catecholamines and glucocorticoids, which alter metabolism and activate transcription factors involved in the acute response. The chronic response to stress is driven by the endocrine system and is associated with altered receptor populations, changing tissue sensitivity to homeostatic signals and resulting in a new physiologic state (Bligh, 1976; Bauman and Currie, 1980). Selye (1946) coined the term "heterostasis" to describe the process of achieving a new equilibrium state following exposure to a stressor (Fink, 2009). The term "rheostasis" was introduced to emphasize that the setpoints for homeostatic regulation may vary across environments or seasons (Mrosovsky, 1990), and the term "enantiostasis" was coined to refer to a situation in which multiple physiological variables are varied to maintain the overall functionality of a system (Mangum and Towle, 1977). These concepts emphasize the idea that maintaining functional homeostasis may require dynamic changes in a variety of parameters. Acclimation to a stress is a phenotypic response developed by the animal to an individual stressor within the environment (Fregley, 1996). However, under natural conditions, it is rare for only one environmental variable to change over time. Acclimatization is the process by which an animal adapts to several stressors within its natural environment (Bligh, 1976). Acclimation and acclimatization are not therefore evolutionary adaptations or natural selection, which are defined as changes allowing for preferential selection of an animal's phenotype and are based on a genetic component passed to the next generation. The altered phenotype of acclimated animals will return to normal if environmental stressors are removed, which is not true for animals that are genetically adapted to their environment (Collier et al., 2004). Acclimatization is a process that takes several weeks to occur, and close examination of this 
process reveals that it occurs via homeorhetic and not homeostatic mechanisms. As described by Bligh (1976), there are 3 functional differences between acclimatory responses and homeostatic or "reflex responses." First, the acclimatory response takes much longer to occur (days or weeks versus seconds or minutes). Second, acclimatory responses generally have a hormonal link in the pathway from the central nervous system to the effector cell. Third, the acclimatory effect usually alters the ability of an effector cell or organ to respond to environmental change.

These acclimatory responses are characteristic of homeorhetic mechanisms as described by Bauman and Currie (1980) and revisited by Bauman (2000) and the net effect is to coordinate metabolism to achieve a new physiological state. Thus, the seasonally adapted animal is different metabolically in winter than in summer. Bauman and Currie (1980) incorporated these characteristics of acclimation into the concept of homeorhesis, which is defined as "orchestrated changes for priorities of a physiological state" (Bauman and Currie, 1980). The concept originated from considering how physiological processes are regulated during pregnancy and lactation (Bauman and Currie, 1980), but application of the general concept has been extended to include different physiological states, nutritional and environmental situations, and even pathological conditions. Key features of homeorhetic controls are its chronic nature (hours and days versus seconds and minutes required for most examples of homeostatic regulation) and its simultaneous influence on multiple tissues and systems that results in an overall coordinated response, which is mediated through altered responses to homeostatic signals (Bauman and Elliot, 1983; Vernon, 1988; Bell and Bauman, 1997).

\section{ENERGY BALANCE}

Stress does not uniformly affect energy balance, which is the difference between energy intake and energy expenditure. Dependent on the stress, phagic drive may be increased (pregnancy, lactation, cold) or decreased (heat, social, immune, calving). Energy expenditure is both increased (pregnancy lactation, cold, immune stress) and decreased (fasting and heat) by stressors. Herein, we review the role of stress on feed intake and energy expenditure in the dairy cow.

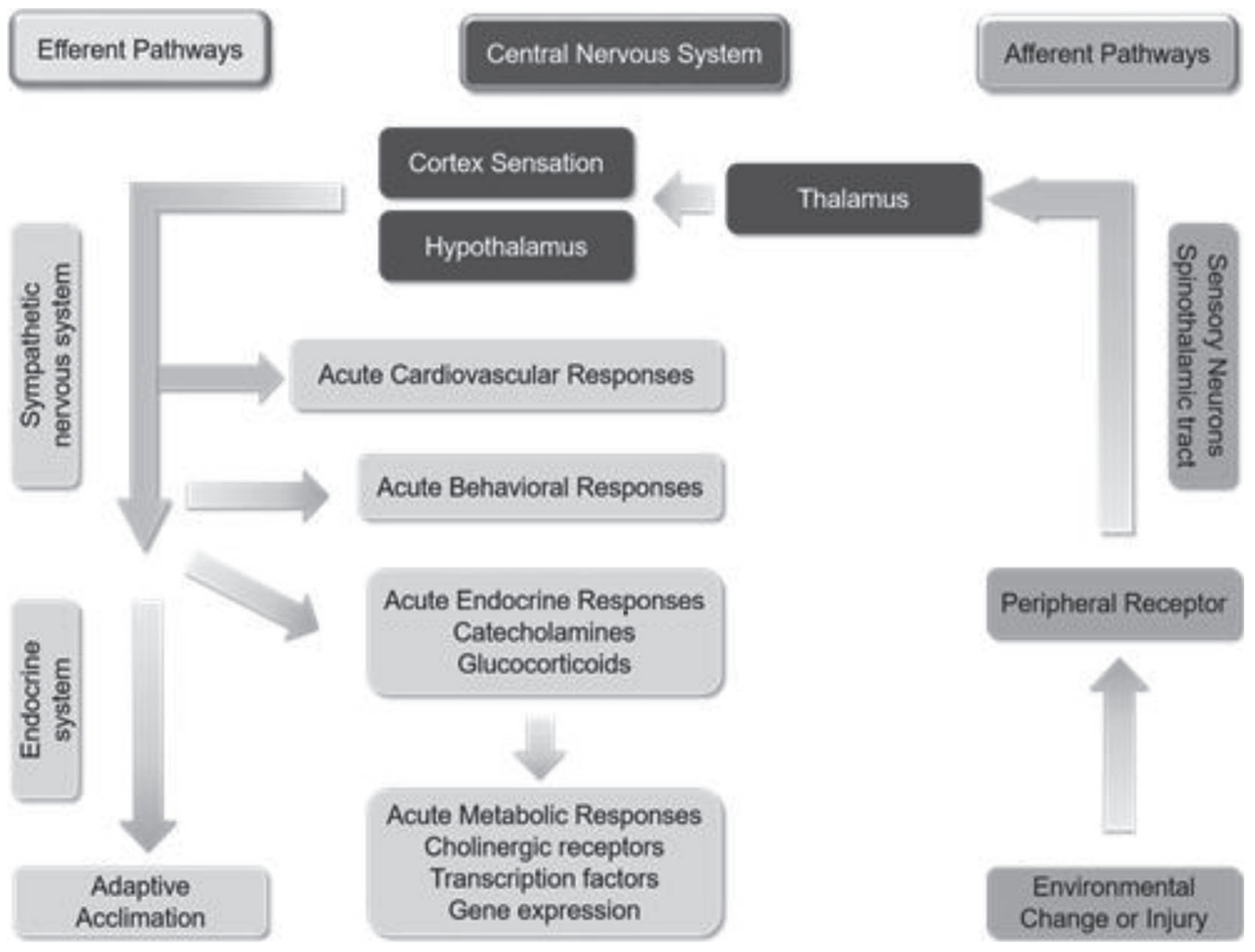

Figure 1. Schematic representation of pathways of stress response. 


\section{Pregnancy and Parturition}

Pregnancy is a primary metabolic requirement in the dairy cow. During the first $180 \mathrm{~d}$ of pregnancy, the metabolic energy requirements $\left(\mathrm{Mcal} / \mathrm{kg}^{0.75}\right)$ increase by approximately $16 \%$. Over the next $105 \mathrm{~d}$, approximately the last one-third of gestation, metabolic demand increases to $175 \%$ of that observed in nonpregnant cows at parturition (Moe and Tyrrell, 1972). In line with this estimate, Brody (1956) showed that heat production increased $59 \%$ during the final $200 \mathrm{~d}$ of pregnancy. On the day of calving, there is a consistent and robust decrease in feed intake (Marquardt et al., 1977; Goff et al., 2002; Huzzey et al., 2007; Lukas et al., 2008). The decrease in feed intake at calving is coincident with a decrease in rumen contractility at calving (Marquardt et al., 1977). Calving is associated with a rise in serum cortisol that is exacerbated in cows that have depleted serum $\mathrm{Ca}^{2+}$ (Horst and Jorgensen, 1982). This may be an adaptive positive feedback response because cortisol increases serum $\mathrm{Ca}^{2+}$. However, the decrease in feed intake is not dependent on a lactation-induced depletion of serum $\mathrm{Ca}^{2+}$ or an increase in serum cortisol, because calving more robustly decreases feed intake in mastectomized cows, which respond to calving with a smaller decrease in $\mathrm{Ca}^{2+}$ and increase in cortisol (Goff et al., 2002). In fact, feed intake remains lower in mastectomized cows than in control cows for the first $4 \mathrm{~d}$ after calving. This suggests that the metabolic demands of lactation are driving the rapid restoration of feed intake postcalving.

\section{Lactation}

The energy demands of lactation often result in a negative net energy balance that remains until $16 \mathrm{wk}$ of lactation (Bauman and Currie, 1980). Brody (1956) reported that at peak lactation, heat production was twice that observed in the dry cow. The increased heat production is partly a result of the increase in energetically expensive organ mass that is required for lactation (Smith and Baldwin, 1974). Obviously, the mammary gland increases in size with lactation $(73 \%)$, but the liver, heart, and lungs are also 22 to $25 \%$ larger in lactation than in dry animals. Indeed, the metabolic demands of the liver increase by $25 \%$. In addition, lactation increases digestive tract mass and energy expenditure by 29 and $28 \%$, respectively. To meet the increased maintenance and lactation energy demands, dairy cows increase feed intake. In fact, DMI more than doubles from precalving to 2 wk postpartum and nearly triples by $7 \mathrm{wk}$ postpartum, reaching maximal values at 12 wk of lactation (Bauman and Currie, 1980; Silanikove et al., 1997). This increase in feed intake is associated with an increased number of meals and simultaneous decrease in total feeding time (Huzzey et al., 2005).

\section{Environmental Cold Exposure}

Cold exposure increases the energy expenditure necessary for the cow to maintain homeothermy and, in turn, drives increases in both energy expenditure and feed intake. Brody (1956) defined the "comfort zone" as the temperature at which no demands are made on the temperature-regulating mechanism and identified this to range between -1 and $15^{\circ} \mathrm{C}\left(30\right.$ and $\left.60^{\circ} \mathrm{F}\right)$ in European cattle (Brody, 1956). Kibler and Brody (1949) demonstrated that a decrease in environmental temperature from 10 to $-15^{\circ} \mathrm{C}\left(50\right.$ to $\left.5^{\circ} \mathrm{F}\right)$ increased heat production 30 to $35 \%$ in lactating Jersey cows and 20 to $30 \%$ in lactating Holstein cows. The more robust increase in energy expenditure in the Jersey cow may be a result of smaller body size or decreased heat of lactation. The metabolic stimulator thyroxine (T4) increases in response to cold exposure and decreases with an increase in temperature (Yousef and Johnson, 1966). This increase in T4 is a mechanism to enhance endothermy. Cows that have higher milk production have a less robust increase in $\mathrm{T} 4$ at $15^{\circ} \mathrm{C}$, which suggests that high-producing dairy cows with high levels of body heat production are not as reliant on T4 for stimulation of metabolic rate in response to a cold environment (Johnson and Vanjonack, 1976). Of note, if cold-exposed cows are not allowed to become hyperphagic in response to a decrease in environmental temperature, the body adapts with high levels of thyroxine to further stimulate metabolic rate. The increase in metabolic rate associated with cold exposure is evident in the metabolic data from calves reared in a cold environment, which have increased serum nonesterified fatty acids and decreased serum glucose, despite consuming more feed.

\section{Environmental Heat Exposure}

Heat has been one of the primary stressors evaluated in dairy science, as the high metabolic demand and associated endothermy makes high-producing dairy cows uniquely sensitive to heat-induced depression of production. In fact, a temperature-humidity index (THI) as low as 78 decreases DMI (Cowley et al., 2015). The decrease in feed intake with heat exposure is likely an adaptive mechanism to decrease heat of digestion and the heat of metabolism (Thompson et al., 1963; Abilay et al., 1975; Magdub et al., 1982). The decrease in feed intake depends on the duration and severity of heat 
exposure (Kibler and Brody, 1949; Brody, 1956; Ominski et al., 2002). Ominski et al. (2002) showed that $5 \mathrm{~d}$ of heat exposure decreased DMI during heat exposure and continued to suppress feed intake for $5 \mathrm{~d}$ under thermoneutral conditions. Interestingly, the THI $2 \mathrm{~d}$ prior appears to most robustly affect feed intake (West et al., 2003), which is in agreement with a previous report by Collier et al. (1981a), that afternoon black globe temperature $2 \mathrm{~d}$ prior had the greatest effect on reduced milk yield. Although the decrease in feed intake associated with heat exposure has been reported to be 60 to $70 \%$ of that in thermoneutral cows (McDowell et al., 1969; Tao and Dahl, 2013), the hyperthermia experienced by the cow is best able to predict the degree of hypophagia. In fact, feed intake is negatively correlated with rectal temperature (Maust et al., 1972; Abilay et al., 1975). This decrease in feed intake plays a primary role in the depression of milk production during heat stress (Wayman et al., 1962; Clark et al., 1972). Accordingly, researchers have focused on physiological adaptations and cooling strategies that may restore feeding.

In response to heat exposure, cows physiologically adapt to depress their heat production and increase heat loss. We have already described how a decrease in feed intake can decrease the heat of digestion. Additionally, because decreasing feed intake depresses milk production, this adaptation also serves to depress the heat of lactation. Heat-stressed cows also upregulate the production of $\beta$-hydroxybutyrate, which binds to GPR109a, the niacin receptor, to induce peripheral vasodilation and enhance evaporative heat loss (Di Costanzo et al., 1997). A decrease in T4 with environmental heat exposure limits the metabolic rate stimulation and heat production of heat-stressed cows (Thompson et al., 1963; Magdub et al., 1982). Finally, the cow increases respiration rate to encourage evaporative heat loss (McDowell et al., 1969; Collier et al., 1981a). This increase in respiration rate is among the most sensitive phenotypic indicators of heat stress; a respiration rate $>60$ breaths per minute is an indicator of heat stress in lactating dairy cows (Shultz, 1984; Berman et al., 1985).

In heat-stressed animals, milk energy output decreases twice as much as digestible energy intake (McDowell et al., 1969). This was confirmed by Wheelock et al. (2010), who demonstrated that only half of the decrease in milk yield could be accounted for by decreases in feed intake. Although milk yield is decreased, the basal metabolic requirements are increased during thermal stress despite a decrease in T4 (Kibler and Brody, 1949, Brody, 1956)
The physiological consequences of heat exposure can be mitigated through management practices that directly cool the dairy cow (Berry et al., 1964). Cooling heat-exposed cows increases feed intake (do Amaral et al., 2009; Tao et al., 2012a). Cooling dry cows increases the gestation length and calf weight at birth and weaning (Tao et al., 2012b). Many strategies to cool dairy cows efficiently have been investigated. Cooling only the head and neck improves feed intake while decreasing body temperature and respiration rate (Roussel and Beatty, 1970). Similarly, cooling the bedding to encourage conductive cooling when the cow is lying down decreases temperature and respiration rate while increasing DMI (Perano et al., 2015; Ortiz et al., 2015). In fact, simply providing bedding materials that remain cooler increases feed intake and time spent resting (Ortiz et al., 2015). Sprinklers that wet the animal, along with ventilation to increase airflow, encourage evaporative cooling and increase feed intake while decreasing water intake (Flamenbaum et al., 1995; Schütz et al., 2011). Although sprinkling with water is effective at lowering body temperature, cows prefer shade (Schütz et al., 2011). Shaded heifers have higher feed intake and better ADG than those that were sprinkled for cooling (Marcillac-Embertson et al., 2009). In cows on pasture, shade availability increases the time spent grazing and the time spent lying (Palacio et al., 2015). Of note, rumen contractions are increased in shaded animals, which may explain the improved feed intake associated with each of these cooling strategies (Collier et al., 1981b).

\section{Health Challenge}

Immune challenges are well established to depress feed intake across species. A lipopolysaccharide-induced immune challenge dose-dependently decreases feed intake in the dairy cow up to nearly $50 \%$ (Waldron et al., 2003). In the dairy cow, mastitis and metritis are immune challenges that occur at high incidence. Mastitis occurs in 10 to $24 \%$ of dairy cows, whereas clinical metritis has been reported to occur in 5.3 to $12.7 \%$ of dairy cows (Wittrock et al., 2011; Ribeiro et al., 2013; Levison et al., 2016). Inclusion of subclinical metritis increases the incidence of metritis to over $40 \%$ (Wittrock et al., 2011). Both mastitis and metritis decrease DMI in relation to severity of infection (Huzzey et al., 2007; Lukas et al., 2008). Severe metritis can depress feed intake by up to $40 \%$, whereas mild metritis results in an $18 \%$ reduction in feed intake (Huzzey et al., 2007). The decrease in DMI may be related to a decrease in feeding time observed in metritic cows (Huzzey et al., 
2007). Lameness, another common malady in dairy cows, similarly decreases feeding time and DMI when lameness scores meet or exceed 4 on a scale of 5 (Norring et al., 2014).

\section{Social Stress}

Social stresses in herd animals such as cattle may include isolation, introduction to a novel group, or limited feed bunk availability. A detailed review of stresses due to housing and other welfare-related situations can be found in this issue (von Keyserlingk and Weary, 2017). Putting a calf into a new group of calves decreases milk intake on the day of introduction (O'Driscoll et al., 2006). However, this effect is acute, as feed intake is not affected by this change in social interaction in the $3 \mathrm{~d}$ following mixing. The decrease in milk intake is associated with a decrease in the number of meals per day and the time on teat. However, there is some compensatory response to the decreased number of meals: intake/meal and feeding rate $(\mathrm{kg} / \mathrm{h})$ are increased. Similarly, putting a cow into a novel group depresses DMI on the day of introduction but not thereafter (Schirmann et al., 2011). This decrease in feed intake is not a result of decreased time at the feed bunk (von Keyserlingk et al., 2008). Feed bunk availability may also affect time spent at the feed bunk. In fact, decreasing feed bunk space from 1 to $0.5 \mathrm{~m} /$ cow decreased the total time spent feeding by $14 \%$ and increased the number of aggressive interactions. Furthermore, decreasing bunk space limits the time spent feeding immediately after fresh feed provision by 24\% (DeVries et al., 2004; Huzzey et al., 2006). A more severe reduction in bunk space results in a further decrease in time spent at the bunk and a more significant relationship between dominance and time spent at the bunk (Friend et al., 1977; Huzzey et al., 2006). Despite these changes in feeding behavior, only one study has shown that limiting bunk space depresses daily DMI and that occurred only when cows were provided $0.1 \mathrm{~m}$ of bunk space/ cow (Friend et al., 1977). Studies with direct competition for a single feeding space have shown that sharing a feeding space increases feeding rate without altering daily DMI (Olofsson, 1999; Hosseinkhani et al., 2008). This suggests that cows adapt their feeding behavior to accommodate a limiting feeding space until the restriction is so severe that it limits feed access throughout the day. Social stressors do alter feed intake in both calves and cows. However, these effects appear to be acute and are not likely to robustly affect production. Social dominance has also been shown to affect feeding behavior, growth rate, metabolic status, and age at onset of puberty (Fiol et al., 2017).

\section{EFFECTS OF STRESS ON METABOLISM}

Several potential metabolic health problems and related interactions of stress and nutrition can arise from physiological responses to stress. Energy and nutrient deficits, respiratory alkalosis, ketosis, and ruminal acidosis are some examples of alterations in metabolism associated with heat stress-induced alterations in nutrient metabolism and balance. Nutritional metabolic changes include alteration in feed consumption and energy and protein metabolism (Baumgard and Rhoads, 2013), water balance, metabolism of electrolytes and associated acid-base imbalance (Beede and Collier, 1986), and endocrine status (Collier et al., 1982b; Rhoads et al., 2009, 2010; Baumgard et al., 2011). Dale and Brody (1954) conducted 2 experiments to study the impact of reduced feed intake during thermal stress on metabolic state. In the first experiment, feed consumption of cows maintained at environmental temperatures above $27^{\circ} \mathrm{C}$ was depressed, thus setting the metabolic circumstances for body fat catabolism. However, these cows did not develop ketosis or even ketonuria. Blood ketone concentrations were actually lower as environmental temperatures increased from 7 to $27^{\circ} \mathrm{C}$, and total urine ketone bodies were not affected. In a second experiment, 4 cows were fasted for $5 \mathrm{~d}$ at $18^{\circ} \mathrm{C}$ (thermal comfort). In contrast to results of the first experiment, blood and urine ketone concentrations increased dramatically after the second day of fasting, suggesting increased fat depot mobilization and incomplete fat oxidation. These 2 experiments emphasized an apparent difference in energy metabolism of animals experiencing similar dramatic reductions in feed intake and carbohydrate oxidation but responding differently, possibly because of differences in general metabolic and physiological state (thermal stress vs. starvation). Later work by Wheelock et al. (2010), Baumgard et al. (2011), and Rhoads et al. (2009, 2011) confirmed these observations and extended these differences to alterations in insulin secretion and clearance and gluconeogenic genes in liver of heat-stressed cows. They proposed that elevated insulin during periods of thermal stress suppresses adipose tissue fatty acid mobilization and is associated with increased catabolism of protein for glucose (Baumgard and Rhoads, 2013). O'Brien et al. (2010) extended these observations to growing cattle, demonstrating that heat stress alters postabsorptive carbohydrate (basal and stimulated) metabolism, characterized primarily by increased basal insulin concentrations and insulin response to a glucose challenge. However, heat stress-induced reduction in feed intake appeared to fully explain decreased ADG in Holstein bull calves. There is currently no mechanism 
to explain increased insulin secretion during heat stress in growing and lactating cattle. Recently, Baumgard and Rhoads (2013) proposed that heat stress impairs gut integrity, leading to influx of endotoxins that could cause some of the metabolic effects detected in heatstressed dairy cows. Additionally, there is scant information on effects of other stressors on metabolism.

\section{IMPACTS OF STRESS ON REPRODUCTION IN DAIRY CATTLE}

Cattle, like most other mammals, have to be bred and deliver calves to initiate and maintain normal lactation. Keeping ideal reproductive performance is important for maximizing the efficiency of milk production in dairy cows. The reproductive processes include production of sperm in males, production of oocytes in females, and embryonic and fetal development. These processes are susceptible to stressors such as heat, cold, handling, and so forth. Heat stress is the best characterized stress and has the most severe impacts on reproductive performance in dairy cattle among all the physiological stressors.

\section{Fertility}

In early studies, the first identified stressor affecting fertility of dairy cows was considered the effect of season. Morgan and Davis (1938) reported the first study on seasonal effects on breeding efficiency in dairy cattle. They went through records of the University of Nebraska dairy herd from 1896 to 1934 . The breeding records covered 2,090 cows from 5 dairy breeds, and the ages of cows and bulls ranged from $<2$ to $18 \mathrm{yr}$. They found that more services were required for conception during the summer season (May to October) than the winter season (November to April) for services between bulls of all ages and cows of all ages. Conception rates were lower during August and September than in other months. Erb et al. (1940) investigated breeding records of the Purdue University dairy herd from 1920 to 1940, and found that the herd had the lowest breeding efficiency during August and highest efficiency in May. Seath and Staples (1941) at Louisiana State University also demonstrated that both of the north and south Louisiana herds required more services per conception in summer than that in other seasons. However, the study conducted by Mercier and Salisbury (1947a,b) at Cornell University demonstrated that the poorest season for breeding dairy cows in eastern Canada and New York State was winter, indicating the presence of adverse effects of cold stress on fertility. These early studies and a comprehensive review (Vincent, 1972) suggested that the impacts of heat and cold stress on fertility of dairy cattle might associate with climates of the region. It may also represent poor ability to detect estrus in stanchion barns during winter months when movement of cows was greatly restricted.

Instead of using seasons to define environmental conditions, Stott and Williams (1962), from the University of Arizona, presented that a lengthened estrous cycle and lowered breeding efficiency in dairy cows were associated with the high temperature and humidity in summer. Ingraham et al. (1974), from Iowa State University, evaluated conception rates of dairy cows in a subtropical climate using THI as an indicator. They reported that conception rate decreased from 55 to $10 \%$ as the THI of the second day before breeding increased from 70 to 84. Gwazdauskas et al. (1975), from the University of Florida, selected the 5 most important factors affecting conception rate from 21 climatological parameters: maximum temperature day after insemination, rainfall day of insemination, minimum temperature day of insemination, solar radiation day of insemination, and minimum temperature day after insemination. These defined environmental indices or factors were helpful not only in recognizing the magnitude of environmental stress on fertility of dairy cows, but also in developing strategies for alleviating the impacts. To that end, scientists in the field began to identify which reproductive processes were affected by these stressors and how.

\section{Sperm Production in Dairy Bulls}

To dissect effects of environmental stress, researchers initially focused on investigating these impacts on fertility of bulls, and Anderson (1941) reported low volume and sperm motility of semen collected from 5 breeds of bulls from May to August in Kenya. Erb et al. (1942) systematically investigated effect of season on semen quality of the dairy bulls. They found that semen volume, sperm concentration, sperm motility, and sperm survival were the lowest and the abnormal sperm number was the greatest in summer months. Their studies indicated that semen production in dairy bulls was impaired during summer. In an attempt to test whether environmental temperatures were involved in the seasonal impacts on semen quality, Casady et al. (1953) studied the reproductive activity of dairy bulls exposed to high ambient temperatures using climatecontrol chambers. When ambient temperature in the chambers increased to $32.2^{\circ} \mathrm{C}$ or higher, they found that bulls showed typical stress symptoms, such as increase in respiration, decrease in body weight, restlessness, and excess salivation. Continuous exposure to high ambient 
temperatures led to decreases in sperm concentration, total count, and motility in the collected ejaculates and adversely affected sperm production in young bulls. With the aid of climate chambers, de Alba and Riera (1966) demonstrated that high ambient temperature lowered semen quality and delayed puberty in Jersey calves. These studies suggested that high temperatures in summer could cause heat stress and impair semen quality. With the emergence of AI, frozen semen techniques, and use of climate-controlled barns for bulls, these negative effects of stress on sperm production in bulls were eliminated in AI semen. However, these effects are still a major issue when bulls are used on farm.

\section{Estrus, Reproductive Hormone Secretion, and Follicle Dynamic in Dairy Cows}

Environmental stress is also deleterious to reproductive performance in females, perhaps even more severe than in males. Stott (1961) studied 2 sets of breeding records: (1) Jerseys, Holsteins, and Guernseys inseminated in Arizona with semen collected in California, Ohio, and Arizona; and (2) cows inseminated inside or outside Arizona at the same time of summer with semen from the same bull in California. He found that, regardless of the source of semen, the Arizona cows demonstrated a substantial decrease in breeding efficiency during summer months; moreover, cows bred outside Arizona had a higher fertility level than those bred in the state using the same semen. He concluded that heat stress effects on females were the major contributor to depressed fertility in summer.

Maintaining normal estrous cycles in dairy cows is essential to control calving intervals, which eventually affects days in milk. Estrus could also be negatively affected by environmental stressors. Hall et al. (1959) observed 1,460 estrous periods of 270 cows and heifers in a 15 -mo period. By comparing the observations reported from the temperate regions, they found lengthened estrous cycles, shortened estrus duration, and decreased estrus intensity in dairy cattle under Louisiana's hot and humid climate. This environmental effect was later confirmed under climatic controlled conditions (Gangwar et al., 1965).

Estrus is driven by reproductive hormone fluctuations, and hormonal activity regulates follicular waves in ovaries during each estrous cycle. Adverse effects of environmental stressor such as elevated ambient temperature on reproductive hormones and follicular dynamic were described in dairy cows as early as the 1970s. Madan and Johnson (1973) investigated effect of thermal stress on the pattern of plasma luteinizing hormone (LH), which is involved in follicle development and ovulation. Guernsey heifers with synchronous estrous cycles were placed in 2 climatic controlled environments (control and heat stress) for 2 consecutive estrous cycles in each environment. The LH in plasma was monitored daily, and the results showed distinctive depression in LH at the LH surge phase of both estrous cycles when heifers were exposed to heat stress conditions. Later, the same laboratory published that heat stress elevated progesterone levels of the first heatexposed estrous cycle but not the second one in heifers (Abilay et al., 1975). Gwazdauskas et al. (1981) induced synchronized estrus in Holstein heifers with prostaglandin $F_{2 \alpha}$, and then measured their hormonal patterns when they were placed in environmental chambers with either thermoneutral or heat stress conditions. The results demonstrated that a decrease in plasma estradiol levels was associated with the heat stress exposure; however, the progesterone in heat-stressed heifers was comparable to that in thermoneutral heifers. William Thatcher's group from the University of Florida described the connections between altered hormonal secretion and follicular development during summer heat stress (Badinga et al., 1993). Lactating cows were assigned to shade with sprinkler-fan cooling system or no shade management system after estrous synchronization. The cows with no shade had smaller first-wave dominant follicles and less follicular fluid in volume at $\mathrm{d}$ 8 of the estrous cycle. In contrast, the subordinate follicles were larger and contained more fluid in cows with no shade, which suggested altered follicular dominance in heat-stressed cows. Estradiol in plasma and the firstwave dominant follicle fluids were decreased from the beginning of summer (July) to the end (September) in the study. Research teams led by M. C. Lucy from the University of Missouri conducted a series of studies focusing on effects of heat stress on serum estradiol levels and the second follicular wave in lactating cows and heifers (Wilson et al., 1998a,b). When comparing lactating cows and heifers in a thermoneutral chamber, heat-stressed animals showed decreased estradiol from d 11 to 21 of the estrous cycle, delayed corpus luteum regression in the proestrus period, and decreased ovulation rate of the second-wave dominant follicles. Collectively, these studies suggested a regulatory axis that heat stress impaired estradiol secretion, which hindered luteolysis, and eventually altered follicle dominance and disrupted ovulation.

Effect of heat stress on other follicular-developmentassociated hormones, such as inhibin, FSH, and androstenedione, were also addressed. An experiment conducted in Israel by Wolfenson et al. (1995) demonstrated that heat stress tended to depress plasma inhibin in heat-stressed lactating cows, and also altered 
the dominance of the first- and second-wave dominant follicles. To evaluate effect of heat stress on follicular functions, Wolfenson et al. (1997) determined hormone production of follicular theca and granulosa cells collected from follicles of the cows in summer, autumn, and winter under thermoneutral and heat-shock culture conditions. Results indicated that estradiol in follicular fluid was lower during fall and winter in cows that were stressed during summer months but was higher in fall and winter in cows that were housed under thermoneutral conditions during summer months. The capacity to produce androstenedione had the same pattern in the theca cells isolated from follicles in different seasonal or heat stress conditions. This study demonstrated adverse effects of heat stress on steroidogenic capacity of follicles, but also suggested delayed effects of heat stress on ovarian functions in dairy cows. Subsequently, the delayed heat stress effect was observed on follicle dynamics in a later study (Roth et al., 2000), and the authors suggested that FSH secretion was upregulated because of downregulated inhibin in plasma in heatstressed cows, resulting in altered follicular dominance and increased incidence of twinning.

Handling related stressors can also cause alterations in reproductive hormones. Thun et al. (1998) investigated hormonal responses of 5 lactating cows under restraint stress, and found that plasma progesterone and LH were increased by a 2 -h immobilization. Mann (2001) reported that stress induced by AI and blood collection increased plasma estradiol at the end of follicular phase and reduced pregnancy rates in dairy cows. However, Szenci et al. (2011) showed that $2 \mathrm{~h}$ of restraint of pregnant heifers at d 30 to 40 of gestation did not affect progesterone levels. Therefore, effects of handling stressors may vary due to type of stress and physiological status of dairy cows.

\section{Oocyte Maturation, Fertilization, and Embryonic and Fetal Development in Dairy Cattle}

Because follicular function could be negatively influenced by stress as described above, impairments on oocyte development and maturation within the affected follicle could be expected. In vivo studies demonstrated that extreme hot or cold conditions during the days before or after insemination led to reduced conception rates in dairy cows (see reviews: Ulberg and Burfening, 1967; Gwazdauskas, 1985), suggesting that oocyte maturation, fertilization, and early embryonic development could be all impaired by environmental stressors. Researchers led by N. L. First (Lenz et al., 1983) examined in vitro maturation and fertilization of oocytes exposed to different temperatures. Oocytes incubated at high temperature $\left(41^{\circ} \mathrm{C}\right)$ had lower nuclear maturation rates, which was likely associated with impaired cellular function of cumulus cells surrounding the oocytes. High $\left(41^{\circ} \mathrm{C}\right)$ or low $\left(35\right.$ or $\left.37^{\circ} \mathrm{C}\right)$ temperature at maturation also decreased the probability of the oocyte being fertilized, and the fertilization process per se was temperature sensitive. Moreover, this study and a later study reported by Peter Hansen's group (Monterroso et al., 1995) from the University of Florida provided evidence that exposure to elevated temperatures in vitro had adverse effects on sperm collected from bovine epididymis or frozen semen, including impaired viability and motility. Collectively, these studies demonstrated that core temperature variation caused by heat or cold stress in dairy cows could be deleterious to fertility of inseminated sperm and oocyte maturation and fertilization.

To reproduce, a mature oocyte has to be fertilized by a sperm to become an embryo. It has been proven that embryonic development in dairy cows is also susceptible to environmental stress. Putney et al. (1988) performed superovulation in Holstein heifers followed by AI and then assigned heifers to either thermoneutral or heat stress chambers. The embryos recovered from heat-stressed heifers had lower percentage of normal quality and higher incidence of abnormal and delayed development compared with those from thermoneutral animals. Just like embryos of some other mammalian species, however, bovine embryos can gain the capacity to resist the effect of maternal heat stress during early development. Ealy et al. (1993) exposed Holstein cows at an unshaded lot in University of Florida Dairy Research Unit to induce heat stress on d 1,3,5, or 7 of pregnancy. Embryonic survival analysis of the embryos recovered on d 8 showed that maternal heat stress had a distinctive negative effect on d 1 of pregnancy but not on days after d 3, suggesting that susceptibility of bovine embryos for heat stress was specific to the developmental stage. This gain of thermotolerance during early development was confirmed by a later in vitro study (Ealy and Hansen, 1994). Taking advantage of the in vitro culture system, the Hansen group demonstrated anti-apoptotic roles of IGF-1 and colony-stimulating factor 2 in increasing survival rates of heat-shocked embryos (Bonilla et al., 2011; Loureiro et al., 2011).

Heat stress during gestation reduced birth weights in rats and sheep (Cartwright and Thwaites, 1967; Benson and Morris, 1971; Brown et al., 1977). Heat stress during gestation also reduced placental weight (Alexander and Williams, 1971) and uterine blood flow (Oakes et al., 1976). The reduction in placental mass or placental function has significant implications for the maternal system (Tao and Dahl, 2013). Altered placental func- 
tion or size may result in altered endocrine dynamics during pregnancy. Several studies have related placental mass or hormone secretion by the placenta to mammary growth or postpartum milk yield (Desjardins et al., 1968; Bolander et al., 1976; Eley et al., 1981). Thus, altered placental function may influence the extent of mammary growth. Pregnant rats subjected to heat stress during the last two-thirds of gestation gave birth to pups of reduced weight and exhibited impaired lactation (Benson and Morris, 1971). Collier et al. (1982b) assigned lactating Holstein cows and heifers to shade or no shade treatments during the dry period beginning in June. Calves born from no shade cows weighed less than those born from cows with shade, and shaded cows produced more milk in the next lactation. Hormonal analysis of the plasma collected from cows during treatment period demonstrated that concentrations of estrone sulfate were lowered by heat exposure. These data demonstrated that heat stress exerted adverse effects on fetal and mammary development by disrupting placental function during pregnancy. Effects of heat stress effects during pregnancy on reproductive performance in the same study were also reported (Lewis et al., 1984). The effects of heat stress during the dry period on postpartum performance of the dam were confirmed by several investigators (reviewed in Tao and Dahl, 2013). Dahl and coworkers have extended the known impacts of heat stress during pregnancy to include effects on growth and survival of the neonate as well as lifetime performance (Tao and Dahl, 2013).

\section{LOOKING AHEAD}

It is clear that producers and consumers are increasingly concerned about the welfare of food animals, and producers know that stressing animals reduces the profitability of their operations. Thus, there will be growing interest in identifying and reducing stressors on dairy farms. Key to continued progress in managing stress on farms will be identification of improved measures of stress that can be applied under practical commercial farming conditions. For example, improvement of the THI to contain specific physiological endpoints for various levels of thermal stress is one example. Biological endpoints such as changes in milk composition may also offer the opportunity to identify impending health issues before their appearance, permitting preventative health interventions. Identifying animal behaviors that are associated with stress responses are also of critical importance. Education of producers to recognize these endpoints will help them to adjust management conditions appropriately to improve welfare of animals on their operations. A better understanding of the regula- tory mechanisms that are responsible for metabolic responses to stress will also lead to improved nutritional management of dairy animals.

\section{REFERENCES}

Abilay, T. A., H. D. Johnson, and M. Madan. 1975. Influence of environmental heat on peripheral plasma progesterone and cortisol during the bovine estrous cycle. J. Dairy Sci. 58:1836-1840.

Alexander, G., and D. Williams. 1971. Heat stress and the development of the conceptus in domestic sheep. J. Agric. Sci. (Camb.) $76: 53$.

Anderson, J. 1941. Further investigations on the semen of the bull. Vet. Rec. 53:197-205.

Badinga, L., W. W. Thatcher, T. Diaz, M. Drost, and D. Wolfenson. 1993. Effect of environmental heat stress on follicular development and steroidogenesis in lactating Holstein cows. Theriogenology 39:797-810.

Bauman, D. E. 2000. Regulation of nutrient partitioning during lactation: Homeostasis and homeorhesis revisited. Pages 311-327 in Ruminant Physiology: Digestion, Metabolism, Growth, and Reproduction. P. B. Cronje, ed. CAB Publishing, New York, NY.

Bauman, D. E., and W. B. Currie. 1980. Partitioning of nutrients during pregnancy and lactation: A review of mechanisms involving homeostasis and homeorhesis. J. Dairy Sci. 63:1514-1529.

Bauman, D. E., and J. M. Elliot. 1983. Control of nutrient partitioning in lactating ruminants. Pages 437-468 in Biochemistry of Lactation. T. B. Mepham, ed. Elsevier Science Publishers B.V., Amsterdam, the Netherlands.

Baumgard, L. H., and R. P. Rhoads. 2013. Effects of heat stress on postabsorptive metabolism and energetics. Annu. Rev. Anim. Biosci. 1:311-337.

Baumgard, L. H., J. B. Wheelock, S. R. Sanders, C. E. Moore, H. B. Green, M. R. Waldron, and R. P. Rhoads. 2011. Postabsorptive carbohydrate adaptations to heat stress and monensin supplementation in lactating Holstein cows. J. Dairy Sci. 94:5620-5633.

Beede, D. K., and R. J. Collier. 1986. Potential nutritional strategies for intensively managed cattle during thermal stress. J. Anim. Sci. 62:543-554.

Bell, A. W., and D. E. Bauman. 1997. Adaptations of glucose metabolism during pregnancy and lactation. J. Mammary Gland Biol. Neoplasia 2:265-278.

Benson, G. K., and L. R. Morris. 1971. Foetal growth and lactation in rats exposed to high temperatures during pregnancy. J. Reprod. Fertil. 27:369-384.

Berman, A., S. Amir, and R. Volcani. 1963. The relationship between the rate of heat production and the level of milk production in a subtropical climate. Aust. J. Agric. Res. 14:874.

Berman, A., Y. Folman, M. Kaim, M. Mamen, Z. Herz, D. Wolfenson, A. Arieli, and Y. Graber. 1985. Upper critical temperatures and forced ventilation effects for high-yielding dairy cows in a subtropical environment. J. Dairy Sci. 68:1488-1495.

Berry, I. L., M. D. Shanklin, and H. D. Johnson. 1964. Dairy shelter design based on milk production decline as affected by temperature and humidity. Trans. Am. Soc. Agric. Eng. 7:329-331.

Bijlsma, R., and V. Loeschcke. 2005. Environmental stress, adaptation and evolution: An overview. J. Evol. Biol. 18:744-749.

Bligh, J. 1976. Introduction to acclimatory adaptation-including notes on terminology. Pages 219-229 in Environmental Physiology of Animals. J. Bligh, J. L. Cloudsley-Thompson, and A. G. Macdonald, ed. John Wiley and Sons, New York, NY.

Bolander, F. F., L. C. Ulberg, and R. E. Fellows. 1976. Circulating placental lactogen levels in dairy and beef cattle. Endocrinology 99:1273-1278.

Bonilla, A. Q., L. J. Oliveira, M. Ozawa, E. M. Newsom, M. C. Lucy, and P. J. Hansen. 2011. Developmental changes in thermoprotective actions of insulin-like growth factor- 1 on the preimplantation bovine embryo. Mol. Cell. Endocrinol. 332:170-179. 
Boonstra, R. 2013. Reality as the leading cause of stress: Rethinking the impact of chronic stress in nature. Funct. Ecol. 27:11-23.

Brody, S. 1956. Climatic physiology of cattle. J. Dairy Sci. 39:715-725.

Brown, D. E., R. I. C. Harrison, F. C. Hinds, H. A. Lewis, and M. H. Wallace. 1977. Heat stress effects on fetal development during late gestation in the ewe. J. Anim. Sci. 44:442-446.

Cartwright, G. A., and C. J. Thwaites. 1967. Foetal stunting in sheep I. The influence of maternal nutrition and high ambient temperatures on the growth and proportion of merino foetuses. J. Agric. Sci. (Camb.) 86:573-580.

Casady, R. B., R. M. Myers, and J. E. Legates. 1953. The effect of exposure to high ambient temperature on spermatogenesis in the dairy bull. J. Dairy Sci. 36:14-23.

Chebel, R. C., P. R. B. Silva, M. I. Endres, M. A. Ballou, and K. L. Luchterhand. 2016. Social stressors and their effects on immunity and health of periparturient dairy cows. J. Dairy Sci. 99:32173228 .

Clark, R., J. Holter, N. Colovos, and H. Hayes. 1972. Effect of postural position and position changes on energy expenditure in fasting dairy cattle. J. Dairy Sci. 55:257-260.

Collier, R., R. Eley, A. Sharma, R. Pereira, and D. Buffington. 1981a. Shade management in a subtropical environment for milk yield and composition in Holstein and Jersey cows. J. Dairy Sci. 64:844-849.

Collier, R. J., L. H. Baumgard, A. L. Lock, and D. E. Bauman. 2004. Physiological limitations, nutrient partitioning. Pages 351-378 in Yields of Farmed Species: Constraints and Opportunities in the 21st Century. J. Wiseman and R. Sylvestor, ed. Nottingham Univ. Press, Nottingham, UK.

Collier, R. J., D. K. Beede, W. W. Thatcher, L. A. Israel, and C. J. Wilcox. 1982a. Influences of environment and its modification on dairy animal health and production. J. Dairy Sci. 65:2213-2227.

Collier, R. J., S. G. Doelger, H. H. Head, W. W. Thatcher, and C. J. Wilcox. 1982b. Effects of heat stress during pregnancy on maternal hormone concentrations, calf birth weight and postpartum milk yield of Holstein cows. J. Anim. Sci. 54:309-319.

Collier, R. J., R. M. Eley, A. K. Sharma, R. M. Pereira, and D. E. Buffington. 1981b. Shade management in subtropical environment for milk yield and composition in Holstein and Jersey cows. J. Dairy Sci. 64:844-849.

Collier, R. J., and K. G. Gebremedhin. 2015. Thermal biology of domestic animals. Annu. Rev. Anim. Biosci. 3:513-532.

Coulombe, R. A. Jr. 1993. Biological action of mycotoxins. J. Dairy Sci. 76:880-891.

Cowley, F. C., D. G. Barber, A. V. Houlihan, and D. P. Poppi. 2015. Immediate and residual effects of heat stress and restricted intake on milk protein and casein composition and energy metabolism. J. Dairy Sci. 98:2356-2368.

Dale, H. E., and S. Brody. 1954. Thermal stress and acid-base balance in dairy cattle. Missouri Agric. Exp. Stn. Res. Bull. 562. University of Missouri, Columbia.

de Alba, J., and S. Riera. 1966. Sexual maturity and spermatogenesis under heat stress in the bovine. Anim. Sci. 8:137-144.

Desjardins, C., M. J. Paape, and H. A. Tucker. 1968. Contribution of pregnancy, fetuses, fetal placentas, and deciduomas to mammary and uterine development. Endocrinology 83:907.

DeVries, T. J., M. von Keyserlingk, and D. Weary. 2004. Effect of feeding space on the inter-cow distance, aggression, and feeding behavior of free-stall housed lactating dairy cows. J. Dairy Sci. $87: 1432-1438$.

Di Costanzo, A., J. N. Spain, and D. E. Spiers. 1997. Supplementation of nicotinic acid for lactating Holstein cows under heat stress conditions. J. Dairy Sci. 80:1200-1206.

do Amaral, B. C., E. E. Connor, S. Tao, J. Hayen, J. Bubolz, and G. E. Dahl. 2009. Heat-stress abatement during the dry period: Does cooling improve transition into lactation? J. Dairy Sci. 92:59885999.

Ealy, A. D., M. Drost, and P. J. Hansen. 1993. Developmental changes in embryonic resistance to adverse effects of maternal heat stress in cows. J. Dairy Sci. 76:2899-2905.
Ealy, A. D., and P. J. Hansen. 1994. Induced thermotolerance during early development of murine and bovine embryos. J. Cell. Physiol. 160:463-468.

Eley, D. S., W. W. Thatcher, H. H. Head, R. J. Collier, and C. J. Wilcox. 1981. Endocrine changes of the conceptus maternal unit in groups of Jersey cows selected for milk yield. I: Periparturient period. J. Dairy Sci. 64:296.

Erb, R. E., F. N. Andrews, and J. H. Hilton. 1942. Seasonal variation in semen quality of the dairy bull. J. Dairy Sci. 25:815-826.

Erb, R. E., J. W. Wilbur, and J. H. Hilton. 1940. Some factors affecting breeding efficiency in dairy cattle. J. Dairy Sci. 23:549.

Fink, G. 2009. Stress: Definition and history. Pages 549-555 in Stress Science: Neuroendocrinology. G. Fink, ed. Academic Press, San Diego, CA

Fiol, C., M. Carriquiry, and R. Ungerfel. 2017. Social dominance in prepubertal dairy heifers allocated in continuous competitive dyads: Effects on body growth, metabolic status, and reproductive development. J. Dairy Sci. 100:2351-2359

Flamenbaum, I., D. Wolfenson, P. L. Kunz, M. Maman, and A. Berman. 1995. Interactions between body condition at calving and cooling of dairy cows during lactation in summer. J. Dairy Sci. $78: 2221-2229$.

Fregley, M. J. 1996. Adaptations: Some general characteristics. Pages 3-15 in Handbook of Physiology. Section 4: Environmental Physiology. Vol. I. M. J. Fregley and C. M. Blatteis, ed. Oxford University Press, Oxford, UK.

Friend, T., C. Polan, and M. McGilliard. 1977. Free stall and feed bunk requirements relative to behavior, production and individual feed intake in dairy cows. J. Dairy Sci. 60:108-116.

Friend, T. H. 1991. Behavioral aspects of stress. J. Dairy Sci. 74:292303.

Gangwar, P. C., C. Branton, and D. L. Evans. 1965. Reproductive and physiological responses of Holstein heifers to controlled and natural climatic conditions. J. Dairy Sci. 48:222-227.

Goff, J. P., K. Kimura, and R. L. Horst. 2002. Effect of mastectomy on milk fever, energy, and vitamins $\mathrm{A}, \mathrm{E}$, and $\beta$-carotene status at parturition. J. Dairy Sci. 85:1427-1436.

Gwazdauskas, F. C. 1985. Effects of climate on reproduction in cattle. J. Dairy Sci. 68:1568-1578.

Gwazdauskas, F. C., W. W. Thatcher, C. A. Kiddy, M. J. Paape, and C. J. Wilcox. 1981. Hormonal patterns during heat stress following PGF2 $\alpha$-tham salt induced luteal regression in heifers. Theriogenology $16: 271-285$.

Gwazdauskas, F. C., C. J. Wilcox, and W. W. Thatcher. 1975. Environmental and management factors affecting conception rate in a subtropical climate. J. Dairy Sci. 58:88-92.

Hall, J. G., C. Branton, and E. J. Stone. 1959. Estrus, estrous cycles, ovulation time, time of service, and fertility of dairy cattle in Louisiana. J. Dairy Sci. 42:1086-1094.

Hamada, T. 1971. Estimation of lower critical temperatures for dry and lactating dairy cows. J. Dairy Sci. 54:1704-1705.

Horowitz, M. 2001. Heat acclimation: Phenotypic plasticity and cues underlying the molecular mechanisms. J. Therm. Biol. 26:357-363.

Horst, R. L., and N. Jorgensen. 1982. Elevated plasma cortisol during induced and spontaneous hypocalcemia in ruminants. J. Dairy Sci. 65:2332-2337.

Hosseinkhani, A., T. DeVries, K. Proudfoot, R. Valizadeh, D. Veira, and M. von Keyserlingk. 2008. The effects of feed bunk competition on the feed sorting behavior of close-up dry cows. J. Dairy Sci. 91:1115-1121.

Huzzey, J. M., T. DeVries, P. Valois, and M. von Keyserlingk. 2006 Stocking density and feed barrier design affect the feeding and social behavior of dairy cattle. J. Dairy Sci. 89:126-133.

Huzzey, J. M., D. Veira, D. Weary, and M. von Keyserlingk. 2007. Prepartum behavior and dry matter intake identify dairy cows at risk for metritis. J. Dairy Sci. 90:3220-3233.

Huzzey, J. M., M. von Keyserlingk, and D. Weary. 2005. Changes in feeding, drinking, and standing behavior of dairy cows during the transition period. J. Dairy Sci. 88:2454-2461. 
Ingraham, R. H., D. D. Gillette, and W. D. Wagner. 1974. Relationship of temperature and humidity to conception rate of Holstein cows in subtropical climate. J. Dairy Sci. 57:476-481.

Johnson, H. D., and W. Vanjonack. 1976. Effects of environmental and other stressors on blood hormone patterns in lactating animals. J. Dairy Sci. 59:1603-1617.

Kibler, H. H., and S. Brody. 1949. Environmental physiology with special reference to domestic animals. 7. Influence of temperature, $50^{\circ}$ to $5^{\circ} \mathrm{F}$ and $50^{\circ}$ to $95^{\circ} \mathrm{F}$, on heat production and cardiorespiratory activities of dairy cattle. Univ. Missouri Agric. Exp. Stn. Res. Bull. 450:3-28.

Kleiber, M. 1961. The Fire of Life. John Wiley and Sons, New York, NY

Lenz, R. W., G. D. Ball, M. L. Leibfried, R. L. Ax, and N. L. First. 1983. In vitro maturation and fertilization of bovine oocytes are temperature-dependent processes. Biol. Reprod. 29:173-179.

Levison, L. J., E. K. Miller-Cushon, A. L. Tucker, R. Bergeron, K. E. Leslie, H. W. Barkema, and T. J. DeVries. 2016. Incidence rate of pathogen-specific clinical mastitis on conventional and organic Canadian dairy farms. J. Dairy Sci. 99:1341-1350.

Lewis, G. S., W. W. Thatcher, E. L. Bliss, M. Drost, and R. J. Collier. 1984. Effects of heat stress during pregnancy on postpartum reproductive changes in Holstein cows. J. Anim. Sci. 58:174-186.

Loureiro, B., L. J. Oliveira, M. G. Favoreto, and P. J. Hansen. 2011. Colony-stimulating factor 2 inhibits induction of apoptosis in the bovine preimplantation embryo. Am. J. Reprod. Immunol. 65:578 588 .

Lukas, J. M., J. K. Reneau, and J. G. Linn. 2008. Water intake and dry matter intake changes as a feeding management tool and indicator of health and estrus status in dairy cows. J. Dairy Sci. 91:3385-3394.

Madan, M. L., and H. D. Johnson. 1973. Environmental heat effects on bovine luteinizing hormone. J. Dairy Sci. 56:1420-1423.

Magdub, A., H. Johnson, and R. Belyea. 1982. Effect of environmental heat and dietary fiber on thyroid physiology of lactating cows. J. Dairy Sci. 65:2323-2331.

Mangum, C., and D. Towle. 1977. Physiological adaptation to unstable environments. Am. Sci. 65:67-75.

Mann, G. E. 2001. Pregnancy rates during experimentation in dairy cows. Vet. J. 161:301-305.

Marcillac-Embertson, N. M., P. H. Robinson, J. G. Fadel, and F. M Mitloehner. 2009. Effects of shade and sprinklers on performance, behavior, physiology, and the environment of heifers. J. Dairy Sci. 92:506-517.

Marquardt, J. P., R. Horst, and N. Jorgensen. 1977. Effect of parity on dry matter intake at parturition in dairy cattle. J. Dairy Sci. 60:929-934.

Maust, L., R. McDowell, and N. Hooven. 1972. Effect of summer weather on performance of Holstein cows in three stages of lactation. J. Dairy Sci. 55:1133-1139.

McDowell, R. E., E. G. Moody, P. J. Van Soest, R. P. Lehmann, and G. L. Ford. 1969. Effect of heat stress on energy and water utilization of lactating cows. J. Dairy Sci. 52:188-194.

Mercier, E., and G. W. Salisbury. 1947a. Seasonal variations in hours of daylight associated with fertility level of cattle under natural breeding conditions. J. Dairy Sci. 30:747-756.

Mercier, E., and G. W. Salisbury. 1947b. Fertility level in artificial breeding associated with season, hours of daylight, and the age of cattle. J. Dairy Sci. 30:817-826.

Moe, P. W., and H. Tyrrell. 1972. Metabolizable energy requirements of pregnant dairy cows. J. Dairy Sci. 55:480-483.

Monterroso, V. H., K. C. Drury, A. D. Ealy, J. L. Edwards, and P. J. Hansen. 1995. Effect of heat shock on function of frozen/thawed bull spermatozoa. Theriogenology 44:947-961.

Morgan, R. F., and H. P. Davis. 1938. Influence of age of dairy cattle and season of the year on the sex ratio of calves and services required for conception. Nebr. Agric. Expt. Sta. Res. Bul. 104:1-19.

Mrosovsky, N. 1990. Rheostasis: The Physiology of Change. Oxford University Press, Toronto, ON, Canada.
Norring, M., J. Häggman, H. Simojoki, P. Tamminen, C. Winckler, and M. Pastell. 2014. Short communication: Lameness impairs feeding behavior of dairy cows. J. Dairy Sci. 97:4317-4321.

O'Brien, M. D., R. P. Rhoads, S. R. Sanders, G. C. Duff, and L. H. Baumgard. 2010. Metabolic adaptations to heat stress in growing cattle. Domest. Anim. Endocrinol. 38:86-94.

O'Driscoll, K., M. A. von Keyserlingk, and D. Weary. 2006. Effects of mixing on drinking and competitive behavior of dairy calves. J. Dairy Sci. 89:229-233.

Oakes, G. K., A. M. Walker, R. A. Ehrenkranz, C. R. Ceflo, and R. A. Chez. 1976. Uteroplacental blood flow during hyperthermia with and without respiratory alkalosis. J. Appl. Physiol. 41:197.

Olofsson, J. 1999. Competition for total mixed diets fed for ad libitum intake using one or four cows per feeding station. J. Dairy Sci. 82:69-79.

Ominski, K. H., A. D. Kennedy, K. M. Wittenberg, and S. A. Moshtaghi Nia. 2002. Physiological and production responses to feeding schedule in lactating dairy cows exposed to short-term, moderate heat stress. J. Dairy Sci. 85:730-737.

Ortiz, X. A.. J. F. Smith, F. Rojano, C. Y. Choi, J. Bruer, T. Steele, N. Schuring, J. Allen, and R. J. Collier. 2015. Evaluation of conductive cooling of lactating dairy cows under controlled environmental conditions. J. Dairy Sci. 98:1759-1771.

Palacio, S., R. Bergeron, S. Lachance, and E. Vasseur. 2015. The effects of providing portable shade at pasture on dairy cow behavior and physiology. J. Dairy Sci. 98:6085-6093.

Perano, K. M., J. G. Usack, L. T. Angenent, and K. G. Gebremedhin. 2015. Production and physiological responses of heat-stressed lactating dairy cattle to conductive cooling. J. Dairy Sci. 98:52525261

Putney, D. J., M. Drost, and W. W. Thatcher. 1988. Embryonic development in superovulated dairy cattle exposed to elevated ambient temperatures between Days 1 to 7 post insemination. Theriogenology 30:195-209.

Rhoads, M. L., J. W. Kim, R. J. Collier, B. A. Crooker, Y. R. Boisclair, L. H. Baumgard, and R. P. Rhoads. 2010. Effects of heat stress and nutrition on lactating Holstein cows: II. Aspects of hepatic growth hormone responsiveness. J. Dairy Sci. 93:170-179.

Rhoads, M. L., R. P. Rhoads, M. J. VanBaale, R. J. Collier, S. R. Sanders, W. J. Weber, B. A. Crooker, and L. H. Baumgard. 2009. Effects of heat stress and plane of nutrition on lactating Holstein cows: I. production, metabolism and aspects of circulating somatotropin. J. Dairy Sci. 92:1986-1997.

Rhoads, R. P., A. J. La Noce, J. B. Wheelock, and L. H. Baumgard. 2011. Short communication: Alterations in expression of gluconeogenic genes during heat stress and exogenous bovine somatotropin administration. J. Dairy Sci. 94:1917-1921.

Ribeiro, E. S., F. S. Lima, L. F. Greco, R. S. Bisinotto, A. P. Monteiro, M. Favoreto, H. Ayres, R. S. Marsola, N. Martinez, W. W. Thatcher, and J. E. Santos. 2013. Prevalence of periparturient diseases and effects on fertility of seasonally calving grazing dairy cows supplemented with concentrates. J. Dairy Sci. 96:5682-5697.

Robertson, W. G. P., J. P. Mixner, W. W. Bailey, and H. D. Lennon. 1958. Effect of certain acute stress conditions on the plasma levels of 17-hydroxycorticosteroids and protein-bound iodine in dairy cattle. J. Dairy Sci. 41:302-305.

Roth, Z., R. Meidan, R. Braw-Tal, and D. Wolfenson. 2000. Immediate and delayed effects of heat stress on follicular development and its association with plasma FSH and inhibin concentration in cows. J. Reprod. Fertil. 120:83-90.

Roussel, J. D., and J. F. Beatty. 1970. Influence of zone cooling on performance of cows lactating during stressful summer conditions. J. Dairy Sci. 53:1085-1088.

Schirmann, K., N. Chapinal, D. Weary, W. Heuwieser, and M. von Keyserlingk. 2011. Short-term effects of regrouping on behavior of prepartum dairy cows. J. Dairy Sci. 94:2312-2319.

Schulte, P. M. 2014. What is environmental stress? Insights from fish living in a variable environment. J. Exp. Biol. 217:23-34.

Schütz, K. E., A. R. Rogers, N. R. Cox, J. R. Webster, and C. B. Tucker. 2011. Dairy cattle prefer shade over sprinklers: Effects on behavior and physiology. J. Dairy Sci. 94:273-283. 
Seath, D. M., and C. H. Staples. 1941. Some factors influencing the reproductive efficiency of Louisiana herds. J. Dairy Sci. 24:510.

Selye, H. 1936. A syndrome produced by diverse nocuous agents. Nature 138:32.

Selye, H. 1946. The general adaptation syndrome and the diseases of adaptation. J. Clin. Endocrinol. Metab. 6:117-230.

Shultz, T. A. 1984. Weather and shade effects on corral cow activities. J. Dairy Sci. 67:868-873.

Silanikove, N., E. Maltz, A. Halevi, and D. Shinder. 1997. Metabolism of water, sodium, potassium, and chlorine by high yielding dairy cows at the onset of lactation. J. Dairy Sci. 80:949-956.

Smith, N., and R. Baldwin. 1974. Effects of breed, pregnancy, and lactation on weight of organs and tissues in dairy cattle. J. Dairy Sci. 57:1055-1060.

Stott, G. H. 1961. Female and breed associated with seasonal fertility variation in dairy cattle. J. Dairy Sci. 44:1698-1704.

Stott, G. H., and R. J. Williams. 1962. Causes of low breeding efficiency in dairy cattle associated with seasonal high temperatures. J. Dairy Sci. 45:1369-1375.

Swanson, E. W., and H. A. Herman. 1944. Seasonal variation in semen quality of some Missouri dairy bulls. J. Dairy Sci. 27:303-310.

Szenci, O., A. Karen, A. C. Bajcsy, A. Gáspárdy, N. M. de Sousa, and J. F. Beckers. 2011. Effect of restraint stress on plasma concentrations of cortisol, progesterone and pregnancy associated-glycoprotein-1 in pregnant heifers during late embryonic development. Theriogenology 76:1380-1385.

Tao, S., and G. E. Dahl. 2013. Invited review: Heat stress effects during late gestation on dry cows and their calves. J. Dairy Sci. 96:4079-4093.

Tao, S., A. P. A. Monteiro, I. M. Thompson, M. J. Hayen, and G. E. Dahl. 2012a. Effect of late-gestation maternal heat stress on growth and immune function of dairy calves. J. Dairy Sci. 95:71287136 .

Tao, S., I. M. Thompson, A. P. A. Monteiro, M. J. Hayen, L. J. Young, and G. E. Dahl. 2012b. Effect of cooling heat-stressed dairy cows during the dry period on insulin response. J. Dairy Sci. 95:50355046 .

Thompson, R., J. Johnston, C. Breidenstein, A. Guidry, M. Banerjee, and W. Burnett. 1963. Effect of hot conditions on adrenal cortical, thyroidal, and other metabolic responses of dairy heifers. J. Dairy Sci. 46:227-231.

Thun, R., C. Kaufmann, and F. Janett. 1998. The influence of restraint stress on reproductive hormones in the cow. Reprod. Domest. Anim. 33:255-260.

Ulberg, L. C., and P. J. Burfening. 1967. Embryo death resulting from adverse environment on spermatozoa or ova. J. Anim. Sci. $26: 571-577$.
Vernon, R. G. 1988. The partition of nutrients during the lactation cycle. Pages 32-52 in Nutrition and Lactation in the Dairy Cow. P. C. Garnsworthy, ed., Elsevier, London, UK.

Vincent, C. K. 1972. Effects of season and high environmental temperature on fertility in cattle: A review. J. Am. Vet. Med. Assoc. 161:1333-1338.

von Keyserlingk, M. A., D. Olenick, and D. Weary. 2008. Acute behavioral effects of regrouping dairy cows. J. Dairy Sci. 91:1011-1016.

von Keyserlingk, M. A. G., and D. M. Weary. 2017. A 100-Year Review: Animal welfare in the Journal of Dairy Science - The first 100 years. J. Dairy Sci. 100:10432-10444. https://doi.org/10.3168/ jds.2017-13298.

Waldron, M. R., T. Nishida, B. Nonnecke, and T. Overton. 2003. Effect of lipopolysaccharide on indices of peripheral and hepatic metabolism in lactating cows. J. Dairy Sci. 86:3447-3459.

Washburn, L. E. 1938. Fasting energy during lactation. J. Dairy Sci. 21:697-704.

Wayman, O., H. D. Johnson, C. P. Merilan, and I. L. Berry. 1962. Effect of ad libitum or force-feeding of two rations on lactating dairy cows subjected to temperature stress. J. Dairy Sci. 45:1472-1478.

West, J. W., B. G. Mullinix, and J. K. Bernard. 2003. Effects of hot, humid weather on milk temperature, dry matter intake, and milk yield of lactating dairy cows. J. Dairy Sci. 86:232-242.

Wheelock, J. B., R. Rhoads, M. VanBaale, S. Sanders, and L. Baumgard. 2010. Effects of heat stress on energetic metabolism in lactating Holstein cows. J. Dairy Sci. 93:644-655.

Wilson, S. J., C. J. Kirby, A. T. Koenigsfeld, D. H. Keisler, and M. C. Lucy. 1998b. Effects of controlled heat stress on ovarian function of dairy cattle. 2. heifers. J. Dairy Sci. 81:2132-2138.

Wilson, S. J., R. S. Marion, J. N. Spain, D. E. Spiers, D. H. Keisler, and M. C. Lucy. 1998a. Effects of controlled heat stress on ovarian function of dairy cattle. 1. Lactating cows. J. Dairy Sci. 81:21242131

Wittrock, J. M., K. L. Proudfoot, D. M. Weary, and M. A. von Keyserlingk. 2011. Short communication: Metritis affects milk production and cull rate of Holstein multiparous and primiparous dairy cows differently. J. Dairy Sci. 94:2408-2412.

Wolfenson, D., B. J. Lew, W. W. Thatcher, Y. Graber, and R. Meidan. 1997. Seasonal and acute heat stress effects on steroid production by dominant follicles in cows. Anim. Reprod. Sci. 47:9-19.

Wolfenson, D., W. W. Thatcher, L. Badinga, J. D. Savio, R. Meidan, B. J. Lew, R. Braw-Tal, and A. Berman. 1995. Effect of heat stress on follicular development during the estrous cycle in lactating dairy cattle. Biol. Reprod. 52:1106-1113.

Yousef, M. K., and H. D. Johnson. 1966. Blood thyroxine degradation rate of cattle as influenced by temperature and feed intake. Life Sci. 5:1349-1363. 


\section{APPENDIX}

Table A1. Timeline of key events in stress physiology

\begin{tabular}{|c|c|c|}
\hline Date & Milestone & Reference \\
\hline 1938 & Fasting energy metabolism during lactation established. & Washburn, 1938 \\
\hline 1944 & Seasonal variation in semen quality identified. & Swanson and Herman, 1944 \\
\hline 1953 & Heat stress adversely affects spermatogenesis in the bull. & Casady et al., 1953 \\
\hline 1954 & Heat-stressed cows in negative energy balance fail to develop ketosis. & Dale and Brody, 1954 \\
\hline 1956 & Breed differences in response to climate reported. & Brody, 1956 \\
\hline 1958 & $\begin{array}{l}\text { Effect of certain acute stress conditions on the plasma levels of } \\
\text { 17-hydroxycorticosteroids. }\end{array}$ & Robertson et al., 1958 \\
\hline 1961 & Lower critical temperature for dairy cattle established. & Kleiber, 1961 \\
\hline 1961 & Fire of Life published. & Kleiber, 1961 \\
\hline 1961 & Upper critical temperature for dairy cattle published. & Berman et al., 1963 \\
\hline 1962 & $\begin{array}{l}\text { Causes of low breeding efficiency in dairy cattle are associated with seasonal } \\
\text { high temperatures. }\end{array}$ & Stott and Williams, 1962 \\
\hline 1963 & Recognition of management relationship to stress in animals. & \\
\hline 1964 & Temperature-humidity index (THI) established. & Berry et al., 1964 \\
\hline 1980 & Concept of homeorhesis defined. & Bauman and Currie, 1980 \\
\hline 1982 & $\begin{array}{l}\text { Heat stress during dry period reduces calf birthweight and postpartum milk } \\
\text { yield of the dam. }\end{array}$ & Collier et al., 1982b \\
\hline 1991 & Behavioral aspects of stress are defined. & Friend, 1991 \\
\hline 1994 & THI categorized into mild, moderate, and severe. & $\begin{array}{l}\text { Armstrong and Wiersma, } \\
1994\end{array}$ \\
\hline 1994 & Effects of heat stress on embryo development are elucidated. & Ealy and Hansen, 1994 \\
\hline 2010 & Carbohydrate and fat metabolism are altered during heat stress, & Wheelock et al., 2010 \\
\hline 2013 & Dry period heat stress effects reported to extend to neonates. & Tao and Dahl, 2013 \\
\hline 2013 & Effects of heat stress on gut integrity and metabolism are shown. & Baumgard and Rhoads, 2013 \\
\hline
\end{tabular}

